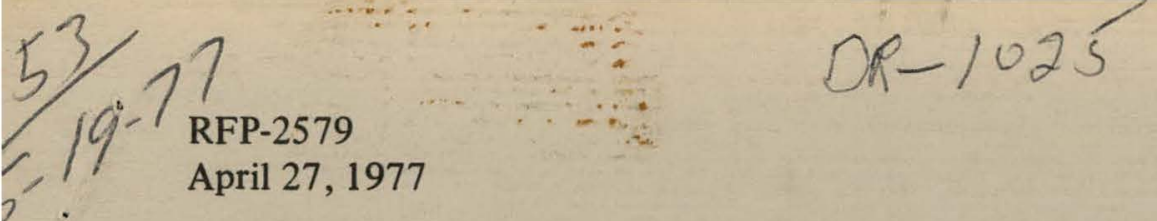

\title{
RECOVERY STUDIES FOR PLUTONIUM MACHINING OIL COOLANT
}

\author{
Chemistry Research and Development
}

James D. Navratil

CHEMICAL RESEARCH GROUP

Charles E. Baldwin

PROCESS CHEMISTRY AND ENGINEERING GROUP

\section{Pockwell Intemational \\ Atomics International Division \\ Rocky Flats Plant \\ P.O. Box 464 \\ Golden, Colorado 80401}

U.S. ENERGY RESEARCH AND DEVELOPMENT ADMINISTRATION CONTRACT EY-76-C-04-3533 


\section{DISCLAIMER}

This report was prepared as an account of work sponsored by an agency of the United States Government. Neither the United States Government nor any agency Thereof, nor any of their employees, makes any warranty, express or implied, or assumes any legal liability or responsibility for the accuracy, completeness, or usefulness of any information, apparatus, product, or process disclosed, or represents that its use would not infringe privately owned rights. Reference herein to any specific commercial product, process, or service by trade name, trademark, manufacturer, or otherwise does not necessarily constitute or imply its endorsement, recommendation, or favoring by the United States Government or any agency thereof. The views and opinions of authors expressed herein do not necessarily state or reflect those of the United States Government or any agency thereof. 


\section{DISCLAIMER}

Portions of this document may be illegible in electronic image products. Images are produced from the best available original document. 


\section{LEGAL NOTICE.}

This report was prepared as an account of work sponsored by the United States Government. Neither the Inited States nor the Energy Research and Development Administration, nor any of their employees, nor any of their contractors, subcontractors, or their employees, makes any warranty, expressed or implied, or assumes any legal liability or responsibility for the accuracy, completeness or usefulness of any information, apparatus, product or process disclosed, or represents that its use would not infringe privately owned rights.

Printed in the United States of America Available from the National Technical Information Service II.S. Department of Commerce Springfield, Virginia 22161 Price: Printed Copy $\$ 4.50$ Microfiche $\$ 3.00$

Price Is Subject to Change Without Notice 
Printed

April 27, 1977
RFP-2579

UC-10 CHEMICAL SEPARATIONS

PROCESSES FOR

PLUTONIUM AND URANIUM

TID-4500-R65

\section{RECOVERY STUDIES FOR PLUTONIUM \\ MACHINING OIL COOLANT}

Chemistry Research and Development

James D. Navratil

CHEMICAL RESEARCH GROUP

Charles E. Baldwin

PROCESS CHEMISTRY AND ENGINEERING GROUP

\section{SUBJECT DESCRIPTORS}

Lathe Coolants

Plutonium

Plutonium Recovery

Separation Processes

Tetrachloromethane

ROCKWELL INTERNATIONAL ATOMICS INTERNATIONAL DIVISION ROCKY FLATS PLANT

P.O. BOX 464

GOLDEN, COLORADO 80401.

Prepared Under Contract EY-76-C-04-3533
This report was NOTICE sponsored by the Urepared as an account of work the United States United States Government. Neither Research and Development the United States Feinergy subcontraployees, nor any of their nor any of subcontractors, or their employees contractors, warranty, express or implied, or assumes maks any or process nes uf any information, appacy, coniplereness infringe privasely, or represents that its

\footnotetext{
for the

Albuquerque Operations Office

U.S. Energy Research and Development Administration
} 
RFP-2579

\section{THIS PAGE \\ WAS INTENTIONALLY \\ LEFT BLANK}




\section{CONTENTS}

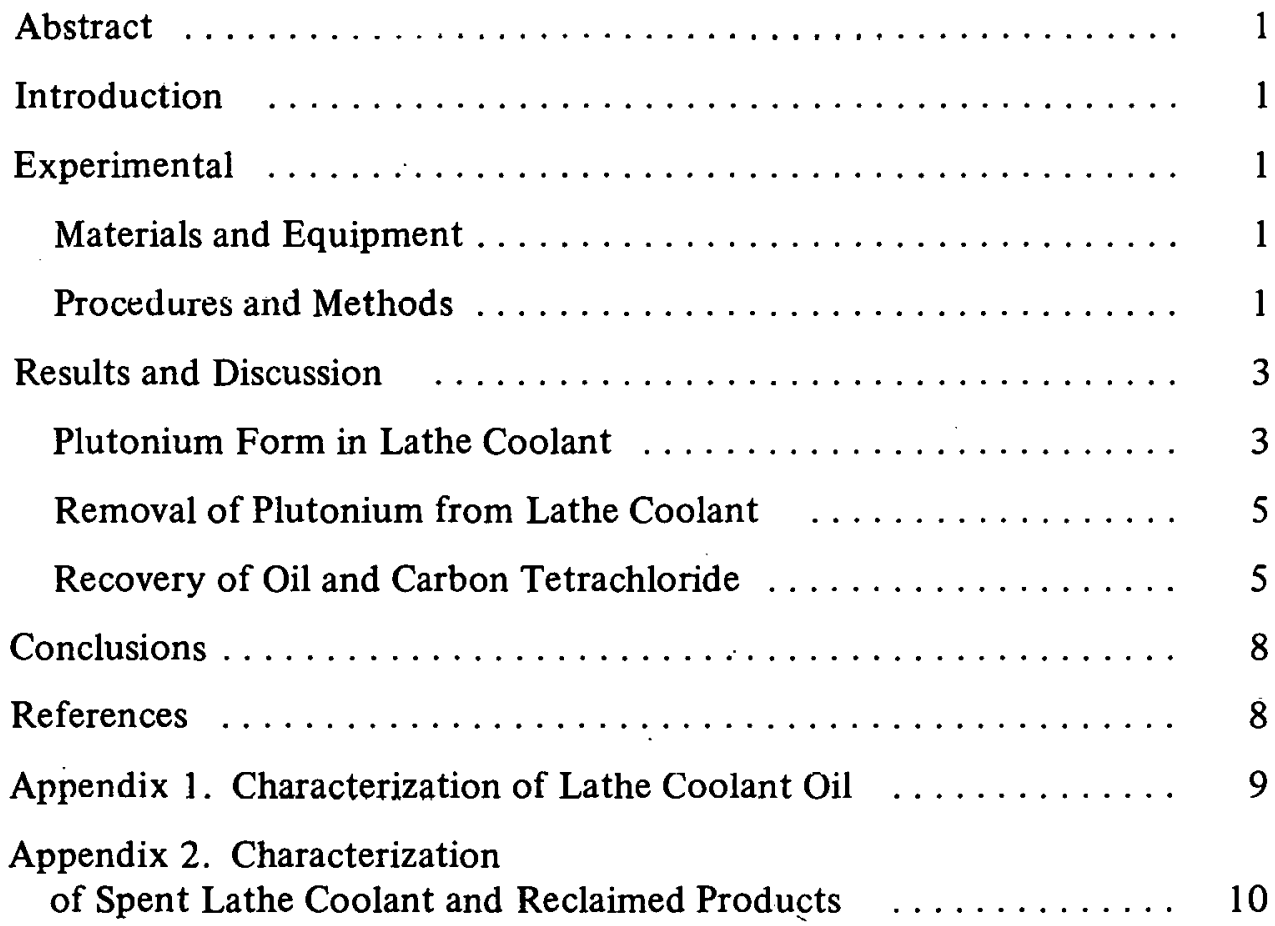




\section{THIS PAGE}

\section{WAS INTENTIONALLY \\ LEFT BLANK}




\section{ACKNOW LED GMENTS}

The authors wish to thank L. R. Crisler for his valuable advice. Appreciation also is extended to personnel in the Analytical Laboratories, especially to R. S. Cichorz and K. J. Grossaint for the analyses; E. F. Lombardi, W. H. James, and A. E. Hodges III for the corrosion tests; and J. A. Hayden for the nuclear track studies. 


\section{THIS PAGE \\ WAS INTENTIONALLY \\ LEFT BLANK}




\title{
RECOVERY STUDIES FOR PLUTONIUM MACHINING OIL COOLANT
}

\author{
James D. Navratil and Charles E. Baldwin
}

\begin{abstract}
Lathe coolant oil, contaminated with plutonium and having a carbon tetrachloride diluent, is generated in plutonium machining areas at Rocky Flats. A research program was initiated to determine the nature of plutonium in this mixture of oil and carbon tetrachloride. Appropriate methods then could be developed to remove the plutonium and to recycle the oil and carbon tetrachloride. Studies showed that the mixtures of spent oil and carbon tetrachloride contained particulate plutonium and plutonium species that are soluble in water or in oil and carbon tetrachloride. The particulate plutonium was removed by filtration; the nonfilterable plutonium was removed by adsorption on various materials. Laboratory-scale tests indicated the lathe-coolant oil mixture could be separated by distilling the carbon tetrachloride to yield recyclable products.
\end{abstract}

\section{INTRODUCTION}

Lathe coolant oil, having a carbon tetrachloride $\left(\mathrm{CCl}_{4}\right)$ diluent and contaminated with plutonium $\mathrm{Pu})$, is generated in plutonium machining areas at Rocky Flats. Each month, spent lathe-coolant oil mixture is filtered $(3 \mu \mathrm{m})$ and stored in two tanks. In addition to the oil, the mixture contains approximately 50 percent carbon tetrachloride and $10^{-3} \mathrm{~g} / 1 \mathrm{Pu}$, which exists in soluble forms or as $<3 \mu \mathrm{m}$ particles. After appropriate analyses have been obtained, the oil is shipped to a waste treatment facility for disposal. The disposal process consists of mixing the oil and carbon tetrachloride with a synthetic, hydrous, calcium silicate powder to produce a solid that can be packaged in 55-gallon drums for storage.

To reduce solid wastes for storage and to conserve materials, a research program was initiated to examine the feasibility of recycling lathe coolant oil and carbon tetrachloride. Since plutonium was not desired in the recycled products, methods to remove plutonium from the spent mixture also were studied. A determination of plutonium species in the oil mixture was therefore needed to assist in the development of plutonium decontamination methods.

\section{EXPERIMENTAL}

\section{Materials and Equipment}

Samples of spent lathe-coolant oil containing carbon tetrachloride were obtained from either of two storage tanks, V-30 or.V-31, in the plutonium machining area at Rocky Flats. The tanks' contents were mixed with an air sparge for 20 minutes before the samples were taken from taps at the bottom of the tanks.

Other materials used in the studies are described in Table 1. Filter holders and $0.01-, 0.1-$, and $0.8-\mu \mathrm{m}$ Millipore $\circledast$ filters* were used as was Whatman 1PS phase separating paper.

\section{Procedures and Methods}

Plutonium decontamination experiments consisted of filtration and adsorption tests. In the filtration tests, mixtures of used lathe-coolant oil were filtered under vacuum through Millipore filters. Plutonium concentrations in the mixtures underwent radiometric, pulse height, and alpha analysis before and after filtration. In the analysis, eight aliquots per original oil sample and four aliquots per filtered sample were counted at least three times each, and the counts were averaged.

For the adsorption tests, $15-\mathrm{ml}$ volumes of the adsorbents were covered with used lathe coolant under static conditions. The oil mixtures with

\footnotetext{
*Manufactured by Millipore Filter Corp., Bedford, Massachusetts.
} 
TABLE 1. Description of Chemicals Used in Experiments

\begin{tabular}{|c|c|c|}
\hline Chemical & Form and/or Purity & Manufacturer \\
\hline Álumina & 80-200 mesh powder & Fisher Scientific Co. \\
\hline $\begin{array}{l}\text { Antioxidant Agent } \\
\text { (2,6-Di-tert.-butyl-4- } \\
\text { methylphenol) }\end{array}$ & Practical & Chem Service \\
\hline Calcium Oxide & $B \& A$ reagent & Allied Chemical Co. \\
\hline $\begin{array}{l}\text { Calcium Sulfate } \\
\text { (Drierite } \otimes \text { ) }\end{array}$ & 10-20 mesh & $\begin{array}{l}\text { W. A. Hammond } \\
\text { Drierite Company }\end{array}$ \\
\hline $\begin{array}{l}\text { Carbon } \\
\text { Tetrachloride }\end{array}$ & Analytical reagent & Mallinckrodt \\
\hline $\begin{array}{l}\text { Cellulose, } \\
\text { Cellex N-1 }\end{array}$ & Non-ionic powder & $\begin{array}{l}\text { Bio-Rad } \\
\text { Laboratories }\end{array}$ \\
\hline Charcoal & Activated ( $1 / 4$ in.) & Barnabey Cheney \\
\hline JM Chromosorb@ & $\begin{array}{l}\text { Caloinod distomito } \\
\text { type } 80-100 \text { mesh }\end{array}$ & Johns-Manville \\
\hline Charcoal & Activated, 6-14 mesh & Fisher Scientific Co. \\
\hline Corn Starch & Powder & Kingman \\
\hline $\begin{array}{l}\text { DMP (2,2- } \\
\text { dimethoxypropane) }\end{array}$ & Reagent grade & $\begin{array}{l}\text { Eastman Organic } \\
\text { Chemicals }\end{array}$ \\
\hline Fullers Earth & - & - \\
\hline Molecular Sieve & $\begin{array}{l}\text { Activated, Type } \\
13 \mathrm{X}, 1 / \mathrm{s} \text { in. }\end{array}$ & Linde \\
\hline Nitric Acid & B\&A reagent grade & Allied Chemical Co. \\
\hline Oil, Texaco $643 \otimes$ & - & Texaco Oil Co. \\
\hline $\begin{array}{l}\text { Polyethylene, } \\
\text { Lot 3-17-174-2 }\end{array}$ & $\begin{array}{l}\text { Beads, } \\
200-600 \text { micron }\end{array}$ & $\begin{array}{l}\text { The Dow Chemical Co., } \\
\text { Louisiana Division }\end{array}$ \\
\hline Polystyrene & Beads, 20-24 mesh & - \\
\hline Sllica Gel & 6-16 mesh & Sargent \\
\hline Sodium Carbonate & Reagent grade, powder & Allied Chemical Co. \\
\hline Sodium Hydroxide & $\begin{array}{l}\text { B\&A reagent } \\
\text { grade, pellets }\end{array}$ & Allied Chemical Co. \\
\hline Sucrose & Granular & Great Western Sugar Co. \\
\hline Teflon® & Powder & Carl Roth OHG \\
\hline $\begin{array}{l}\text { TEOF (triethyl- } \\
\text { orthoformate) }\end{array}$ & Reagent & $\begin{array}{l}\text { Eastman Organic: } \\
\text { Chemicals }\end{array}$ \\
\hline
\end{tabular}

and without (for control) adsorbents were stored for various periods of time. The entire oil mixtures (samples) were filtered $(0.01 \mu \mathrm{m})$ separately and then analyzed for plutonium. The difference between analyses of the treated oil and the control oil samples was used to calculate the percent of soluble plutonium removed.
Column tests also were used to test the adsorbents. Fractions $(15 \mathrm{ml})$ of the oil mixtures were passed through a $1.4-\mathrm{cm}$-diameter by $3.2-\mathrm{cm}$-high column of the adsorbent at a $10 \mathrm{ml} / \mathrm{hr}$ flow rate. Each oil fraction was filtered through a $0.01-\mu \mathrm{m}$ filter and analyzed for plutonium.

Tests with dehydrating reagents consisted of storing $2 \mathrm{ml}$ of either DMP or TEOF with $5 \mathrm{ml}$ of oil mixture in sealed vials. The oil mixture was filtered $(0.01 \mu \mathrm{m})$ and analyzed for plutonium.

Plutonium decontamination tests with $10 \mathrm{M}$ sodium hydroxide $(\mathrm{NaOH})$ or with $7 M$ nitric acid $\left(\mathrm{HNO}_{3}\right)$ and $0.1 M$ hydrofluoric acid (HF) consisted of mixing equal volumes of both phases for 5 minutes. The phases were then separated for 10 minutes, and each phase was analyzed for plutonium.

Experiments were conducted to measure the effect of the antioxidant agent (2,6-Di-tert-butyl-4methylphenol) on the growth of nonfilterable plutonium in mixtures of oil and carbon tetrachloride. The experiments consisted of dissolving $0,100,1000$, and $10,000 \mathrm{mg} / \mathrm{l}$ of antioxidant agent in duplicate batches of Texaco 643 oil (free of antioxidant) conilaining 50 vol $\% \mathrm{CCl}_{4}$ and 0.1 vol \% water $\left(\mathrm{H}_{2} \mathrm{O}\right)$. Plutonium metal coupons ( $0.1-\mathrm{cm}$ thick by $2.4-\mathrm{cm}$ diameter), free of surface oxidation, were stored in the oil and carbon tetrachloride batches-some for 15 days and others for 66 days. After storage, the batches were filtered through a $0.2-\mu \mathrm{m}$ Millipore filter and sampled in triplicate for plutonium.

The spent lathe coolant and recovered oil and carbon tetrachloride samples were characterized by analysis. Relative hydrocarbon oxidation was measured as volume percent dibutyl sebacate hy infrared spectroscopy. Observed degradation was determined by comparing relative differences in the infrared spectra of $0.1-\mathrm{mm}$ films of a fresh oil sample and of sample oils after volatile constituents had been removed. Subtle differences were detected in the $1300-$ to $670-\mathrm{cm}^{-1}$ region indicating chain cleavage, dehydrogenation, oxidation, and nitration. Volume percent of carbon tetrachloride was determined by measuring the percent volatiles. The $\mathrm{pH}$ and chloride contents of the oils were determined by potentiometric methods after a 
1:1 water extraction. Water content was determined by Karl Fisher coulometric titration.

Characterization of soluble plutonium species in the oil was attempted by chromatographic massspectroscopy techniques. Filtered oil mixtures were introduced into a $1.3-\mathrm{cm}$-diameter column packed with alumina. That was followed by slow elution with $50 \mathrm{ml} \mathrm{CCl}_{4}$. The discolored portion of the alumina was heated and the outgas analyzed by mass spectroscopy to obtain fragmentation patterns of the adsorbed species.

The corrosion tests were accomplished by the conventional weight-loss method. The method involved storing treated plutonium coupons (surface area of about $7 \mathrm{~cm}^{2}$ ) in each oil sample at ambient temperatures. After storage, the coupons were treated as before storage, i.e., wire brushed to remove surface corrosion, rinsed in 1,1,1-trichloroethane, dried, and weighed to the nearest $0.1 \mathrm{mg}$. The weight difference of the coupon before and after storage was used to calculate the corrosion rate.

X-ray diffraction techniques were used to identify the plutonium species filtered from the oil. The oil was filtered through $0.05-\mu \mathrm{m}$ Millipore filters, and the filter and residue were subjected immediately to $\mathrm{X}$ rays without removing the oil coating from the residue. Nuclear track techniques were used to determine the physical form of plutonium in the filtered oil mixtures.

Carbon tetrachloride was separated from spent lathe-coolant mixtures by simple distillation techniques. The distillation equipment consisted of a 500-ml flask connected to an air-cooled condenser. The distillation occurred at a vapor temperature of $\sim 80^{\circ} \mathrm{C}$ under atmospheric pressure $(\sim 610 \mathrm{~mm} \mathrm{Hg})$.

\section{RESULTS AND DISCUSSION}

\section{Plutonium Form in Lathe Coolant}

Oil samples were taken over a period of several months from the plutonium machining storage tanks and were characterized by chemical analysis.
Plutonium decontamination experiments were also conducted to determine whether plutonium in the lathe coolant oil was present as suspended particulate or as a form that is soluble in water or in a mixture of oil and carbon tetrachloride.

Characterization and decontamination results are shown in Tables 2 and 3. The original samples taken in September contained a large amount of visible particulate matter (V-30 more so than V-31) compared to the October samples. These observations correlate with the decrease in plutonium concentration after filtering the oil samples through an $0.8-\mu \mathrm{m}$ Millipore filter. In most cases, the plutonium concentration did not decrease significantly by filtering with $0.1-$ or $0.01-\mu \mathrm{m}$ Millipore filters when compared to $0.8-\mu \mathrm{m}$ filtering. The plutonium concentration also did not change significantly after filtering through phase separating paper; however, after storage over anhydrous calcium sulfate for six days, and subsequent filtering through $0.01-\mu \mathrm{m}$ filters, the alpha count was near background of available radiometric counting equipment $(\sim 1 \mu \mathrm{g} / 1 \mathrm{Pu})$.

These results show that particulate and soluble plutonium species are present in mixtures of oil and carbon tetrachloride. The nonfilterable (soluble) plutonium remaining in the monthly samples of oil and carbon tetrachloride averaged $50 \times 10^{-5} \mathrm{~g} / \mathrm{l}$ over a period of a year. Nuclear track techniques confirmed the filtered oil was free of plutonium-containing particulate matter. The concentration and percentage of nonfilterable plutonium, shown in Tables 2 and 3 , varied over a wide range. No correlation was found with the chemical analysis that was performed except perhaps in chloride content. A statistical test showed no significant correlation between the amounts of nonfilterable plutonium and chloride concentrations, but because each sample had a different history and length of plutonium and carbon tetrachloride interaction time, a real correlation may have gonc undetected.

The amount of nonfilterable plutonium in the samples of oil and carbon tetrachloride decreased, and the chloride concentration and $\mathrm{pH}$ generally increased after 3 to 10 months storage in sealed polyethylene bottles (see Appendix 1). The decrease 
TABLE 2. Results of Decontamination Experiments

Description

Sample date and tank number

Untreated oil sample

Filtered $(0.8 \mu \mathrm{m})$

Filtered $(0.1 \mu \mathrm{m})$

Filtered $(0.01 \mu \mathrm{m})$

Filtered through $0.01-\mu \mathrm{m}$ Millipore and Whatman 1PS phase separating paper

Stored over calcium sulfate, Filtered $(0.01 \mu \mathrm{m})$
Average Plutonium Concentration $\left(10^{-3} \mathrm{~g} / \mathrm{l}\right) \pm$ Standard Dcviation

\begin{tabular}{|c|c|c|c|c|c|c|c|c|c|}
\hline \multicolumn{3}{|c|}{ Scpt V-30 } & \multicolumn{2}{|c|}{ Sept V-31 } & \multicolumn{2}{|c|}{ Oct V-30 } & \multicolumn{2}{|c|}{ Oct V-31 } & Jan V-30 \\
\hline 886 & \pm 2 & & 116 & \pm 26 & 157 & \pm 11 & 143 & \pm 36 & $57 \pm 4$ \\
\hline 164 & \pm & 1 & 35 & \pm 2 & & \pm 1 & 63 & \pm 6 & $1.2 \pm 0.2$ \\
\hline 144 & \pm & 4 & 23 & \pm 2 & .78 & \pm 4 & 62 & \pm 7 & $1.8 \pm 0.3$ \\
\hline 144 & \pm & 2 & 22 & \pm 2 & 81 & \pm 4 & 81 & \pm 5 & $1.2 \pm 0.3$ \\
\hline 144 & \pm & 7 & & \pm 2 & 81 & \pm 7 & 83 & \pm 1 & - \\
\hline 0.5 & & 0.2 & & \pm 0.1 & & \pm 0.3 & & \pm 0.5 & $0.1 \pm 0.1$ \\
\hline
\end{tabular}

\section{Description}

Saunple dale and lank numbes

Untreated oil sample

Filtered $(0.8 \mu \mathrm{m})$

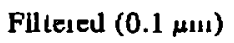

Filtered $(0.01 \mu \mathrm{m})$

Filtered through $0.01-\mu \mathrm{m}$ Millipore and Whatman 1PS phase separating paper

Stored over calcium sulfate, Filtered $(0.01 \mu \mathrm{m})$
Average Plutonium Concentration $\left(10^{-5} \mathrm{~g} / \mathrm{l}\right) \pm$ Standard Deviation

\begin{tabular}{|c|c|c|c|c|}
\hline Jan V-31 & Apr V 30 & Apr V a1 & June V-30 & Aug V-31 \\
\hline $31 \pm 1:$ & $60 \pm 8$ & $46 \pm 3$ & $102 \pm 10$ & $160 \pm 15$ \\
\hline $3.6 \pm 0.5$ & $31 \pm 1$ & $12 \pm 1$ & $70 \pm 6$ & $47 \pm 4$ \\
\hline $3.0 \perp 0.5$ & 10 由3 & $11 \bullet 1$ & $66 \div 4$ & $51+5$ \\
\hline $2.4 \pm 0.4$ & $32 \pm 2$ & $8.4 \pm 0.5$ & $68 \pm 5$ & $59 \pm 4$ \\
\hline- & - & - & - & - \\
\hline $0.2 \pm 0.2$ & $0.1 \pm 0.2$ & $0.1 \pm 0.1$ & $0.6 \pm 0.2$ & - \\
\hline
\end{tabular}

TABLE 3. Characterization of Lathe Coolant Oil

\begin{tabular}{|c|c|c|c|c|c|c|c|c|c|c|}
\hline \multirow{2}{*}{$\frac{\text { Description }}{\text { Sample date and tank number }}$} & \multicolumn{10}{|c|}{ Results of Analyses } \\
\hline & Sept V-30 & Sept V-31 & Oct V-30 & Oct V-31 & Jan $V-30$ & Jan V-31 & Apr V-30 & Apr V-31 & June V-30 & Aug V-31 \\
\hline Nonfilterable plutonium (wt $\%)^{\mathrm{a}}$ & 16 & 19 & 45 & 43 & 2 & 8 & 52 & 18 & 65 & 29 \\
\hline Carbon tetrachloride (vol \%) ${ }^{b}$ & 45 & 37 & 45 & 63 & 54 & 55 & 59 & 68 & 69 & 70 \\
\hline $\mathrm{pH}$ & 2.6 & 3.0 & 2.9 & 2.9 & 3.0 & 3.0 & 3.4 & 2.7 & 6.2 & 2.2 \\
\hline Chloride $\left(10^{-3} M\right)$ & 8.2 & 2.3 & 3.3 & 8.4 & 2.2 & $4.1:$ & 4.8 & 6.3 & 6.0 & 2.8 \\
\hline
\end{tabular}

of soluble plutonium could have been caused by adsorption of plutonium onto the polyethylene bottle and/or precipitation of the plutonium.

No method for determining water concentrations below $1000 \mathrm{ppm}$ was available at this point, but later analyses showed the mixtures of oil and carbon tetrachloride contained an average of 33 microliters per liter of water (see Appendix 2).

Nonfilterable plutonium remaining in the oil [approximately $0.005 \mathrm{~m} M$ (millimolar) $\mathrm{Pu}$ ] was 
presumed to be present as hydrated chloro species since the mixture usually contained about $0.002 \mathrm{~m} M$ water and about $0.14 \mathrm{~m} M$ chloride. Another potential ligand or complexing agent for plutonium in the oil mixtures is the $\sim 3$ wt $\%$ antioxidant agent (2,6-Di-tert.-butyl-4-methylphenol) present in the oil.

Experiments were performed with plutonium metal coupons stored in batches of synthetic oil and carbon tetrachloride mixtures. These mixtures contained various amounts of the antioxidant agent. Results showed increasing levels of nonfilterable plutonium with increasing concentrations of antioxidant (Table 4). The data suggest only the possibility of a soluble 2,6-Di-tert.-butyl-4methylphenol plutonium complex being formed in the mixtures of oil and carbon tetrachloride.

Attempts to characterize the actual plutonium species in the oil mixture by separation-mass spectroscopy techniques failed. The particulate plutonium removed by filtration averaged $1 \mathrm{mg} / \mathrm{l}$ and was identified by X-ray diffraction techniques as plutonium dioxide. No evidence for plutonium metal or other plutonium compounds was observed.

\section{Removal of Plutonium from Lathe Coolant}

The particulate plutonium in the untreated lathe coolant was not entirely removed by filtering through $3-\mu \mathrm{m}$ production filters as shown in Table 2. Filtering with $<0.8-\mu \mathrm{m}$ Millipore filters, however, appears to remove almost all of the plutonium particles.

Soluble plutonium was found to be removable $(<0.01 \mathrm{mg} / \mathrm{l})$ by adsorption on alumina, calcium sulfate, calcium oxide, charcoal, Fuller's earth, JM Chromosorb, and molecular sieves, or by contact with $7 M \mathrm{HNO}_{3}-0.1 M \mathrm{HF}$. Only alumina, Chromosorb, and Fuller's earth had fast enough adsorption rates to remove plutonium in a column at $10-\mathrm{ml} / \mathrm{hr}$ flow rates. Results indicate the other reagents, shown in Table 5, were not entirely effective. Treatment of the June V-30 oil sample with dehydrating agents (DMY and 'lEOF) reduces the amount of soluble plutonium somewhat, indicating possibly that removal of water causes some precipitation of the plutonium.
TABLE 4. Effect of Antioxidant Agent on the Growth of Soluble Plutonium in Mixture of Oil and Carbon Tetrachloride

\begin{tabular}{|c|c|c|}
\hline \multirow{2}{*}{$\begin{array}{l}\text { Antioxidant Agent }{ }^{\mathrm{a}} \\
\ldots \quad(\mathrm{mg} / \mathrm{l})\end{array}$} & \multicolumn{2}{|c|}{$\begin{array}{l}\text { Soluble Plutonium } \\
\text { (mg/l) }\end{array}$} \\
\hline & 15 days storage & 66 days storage \\
\hline 0 & 11 & 18 \\
\hline 100 & - & 42 \\
\hline 1,000 & 35 & 63 \\
\hline 10,000 & - & 85 \\
\hline $\begin{array}{l}\text { a. 2,6-Di-tert. butyl- } \\
\text { b. Average of triplic }\end{array}$ & $\begin{array}{l}\text { ylphenol. } \\
\text { lysis. }\end{array}$ & $\cdot$ \\
\hline
\end{tabular}

The use of alumina, JM Chromosorb, and Fuller's earth in a routine process probably would generate excessive waste, especially since regeneration of the reagents appeared unlikely. The most compatible reagents for a plutonium recovery facility were charcoal for adsorption and nitric acid plus hydrofluoric acid, which were used for washing. The charcoal could be incinerated, and the acids could be disposed of in the plutonium waste stream. The acid scrub would not permit reuse of the oil, but charcoal would. Plutonium adsorption kinetics would have to be studied further, however, before charcoal adsorption could be considered in a plutonium removal process. (Other types of charcoals and smaller particle size charcoal also should be studied.)

\section{Recovery of Oil and Carbon Tetrachloride}

To determine the feasibility of recovering and recycling used oil for lathe coolant, various oil samples were subjected to conventional (weight loss), plutonium-metal corrosion tests. The results of plutonium corrosion in new Texaco 643 oil and two, used mixtures of oil and carbon tetrachloride are shown in Table 6.

Plutonium corrosion relative to new oil was increased when water and carbion tetrachloride were present, especially when present together. 
RFP-2579

TABLE 5. Removal of Soluble Plutonium from Mixture of Oil and Carbon Tetrachloride Using Various Reagents

\begin{tabular}{|c|c|c|c|c|}
\hline \multirow[b]{2}{*}{ Reagent $^{a}$} & \multirow[b]{2}{*}{$\begin{array}{l}\text { Soluble Plutonium Removed in Column } \\
\qquad(w \mathrm{t} \%)\end{array}$} & \multicolumn{3}{|c|}{$\begin{array}{l}\text { Soluble Plutonium Removed after Static Storage } \\
\text { (wt \%) }\end{array}$} \\
\hline & & 1 day & 2 days & 6 days \\
\hline Alumina & 99.5 & 85 & 99.1 & 99.8 \\
\hline JM Chromosorb & 99.5 & 98 & 99.6 & - \\
\hline Fuller's Earth & 99.5 & 97 & $>99.9$ & - \\
\hline Molecular Sieve & 48 & > & - & - \\
\hline Calcium Sulfate & 34 & 97 & 98 & 99.1 \\
\hline Calcium Oxide & - & 99 & 99.5 & - \\
\hline Charcoal & 50 & 99 & - . & - \\
\hline Coconut Charcoal & 46 & 80 & 90 & 98 \\
\hline Silica Gel & - & 47 & 73. & 92 \\
\hline Cellex N-1 & 90 & 88 & - & - \\
\hline Powdered Calcium Sulfate & 70 & 69 & - & - \\
\hline Sodium Hydroxide & - & 21 & 32 & 48 \\
\hline Sucrose & 8 & 43 & - & - \\
\hline Sodium Carbonate & - & 23 & - & - \\
\hline Corn Starch & 61 & 21 & - & - \\
\hline Polyethylene & - & 0 & 4 & 20 \\
\hline Teflon & - & 0 & 1 & 18 \\
\hline Polystvrene & - & 9 & 11 & - \\
\hline DMP (2,2-dimethoxypropane) & - & 17 & 24 & 49 \\
\hline TEOF (triethylorth oformate) & - & 0 & 15 & 43 \\
\hline IQM Soḍium Hydroxide & - & $81^{d}$ & - & - \\
\hline $7 M$ Nitric Acid and $0.1 M$ Hydrofluoric Acid & - & $97^{d}$ & - & - \\
\hline $\begin{array}{l}\text { a. See Table } 1 \text { for reagent description. } \\
\text { b. Passed } 14 \mathrm{ml} \text { of June V-30 mixture of oil } \\
\text { flow rate. } \\
\text { c. Stored } 15 \mathrm{ml} \text { of reagent covered with Jun } \\
\text { carbon tetrachloride and } 2 \mathrm{ml} \text { dehydrating } \\
\text { d. Contacted for } 5 \text { minutes. }\end{array}$ & $\begin{array}{l}\text { d carbon tetrachloride through } 3.2-\mathrm{cm} \text {-iong, } \\
-30 \text { mix ture of oil and carbon tetrachloride } \\
\text { gent or equal volumes of aqueous solutions }\end{array}$ & $\begin{array}{l}\text { 4-cm-dlameter } \\
\text { sealed vials or } \\
\text { d mix ture of oil }\end{array}$ & $\begin{array}{l}\text { n of reag } \\
\text { 5-ml mix } \\
\text { arbon te }\end{array}$ & $\begin{array}{l}10 \mathrm{ml} / \mathrm{h} \\
\text { of oil and } \\
\text { loride. }\end{array}$ \\
\hline
\end{tabular}

New oil with carbon tetrachloride added and then removed by distillation (to $<0.1$ percent) showed no more corrosion than new oil. Used mixtures of oil and carbon tetrachloride were much more corrosive than new oil, but plutonium corrosion decreased when the carbon tetrachloride was removed (to $<0.1$ percent), and reduced further after contact with charcoal.
Corrosion results showed that used oil with the carbon tetrachloride removed (to $<0.1$ percent) was not as good as new oil. Treatment with charcoal appears to reduce the corrosive behavior of recycled oil. Plutonium corrosion in oil bottoms containing $<3$ percent carbon tetrachloride (resulting from distillation of several spent lathe-coolant mixtures; see Appendix 2) was about the same as 
TABLE 6. Results of Plutonium Corrosion Tests with Lathe Coolant Oil

\begin{tabular}{|c|c|c|c|}
\hline \multirow[b]{2}{*}{ Description of Lathe Coolant } & \multicolumn{3}{|c|}{$\begin{array}{c}\text { Plutonium Corrosion } \\
\left(\mathrm{mg} / \mathrm{dm}^{2} \cdot \text { day }\right)^{\mathrm{a}} \\
\text { After }\end{array}$} \\
\hline & 2 weeks & 4 weeks & 8 weeks \\
\hline None (air) & 14 & 10 & 5 \\
\hline New oil & 17 & 10 & 6 \\
\hline New oil +0.02 vol $\% \mathrm{H}_{2} \mathrm{O}$ & - & 15 & - \\
\hline New oil +0.1 vol $\% \mathrm{H}_{2} \mathrm{O}$ & 58 & 21 & 15 \\
\hline New oil +1 vol $\% \mathrm{H}_{2} \mathrm{O}$ & 56 & 10 & 9 \\
\hline New oil +0.1 vol $\% \mathrm{CCl}_{4}$ & 25 & 12 & 8 \\
\hline $\mathrm{New}$ oil +1 vol $\% \mathrm{CCl}_{4}$ & 27 & 21 & 11 \\
\hline $\begin{array}{l}\text { New oil }+0.1 \text { vol } \% \mathrm{H}_{2} \mathrm{O}+0.1 \\
\quad \text { vol } \% \mathrm{CCl}_{4}\end{array}$ & - & 73 & - \\
\hline $\begin{array}{l}\text { New oil with } \mathrm{CCl}_{4} \text { added, } \\
\text { then removed }(<0.1 \text { vol \%) }\end{array}$ & - & 9 & - \\
\hline June V.30 oil- $\mathrm{CCl}_{4}$ & - & 32 & - \\
\hline June V-30 $\mathrm{CCl}_{4}(<0.1$ vol \%) removed & - & 17 & - \\
\hline $\begin{array}{l}\text { June V-30 CCl } \\
\qquad(<0.1 \text { vol \%) charcoal treated }\end{array}$ & - & 14 & - \\
\hline $\begin{array}{l}\text { June } \mathrm{V}-30 \mathrm{CCl}_{4}(<0.1 \text { vol \%) } \\
\text { charcoal, } \mathrm{CaSO}_{4} \text { treated }^{\mathrm{b}}\end{array}$ & - & 14 & - \\
\hline Jan V-30 oil- $\mathrm{CCl}_{4}$ & 27 & 19 & 12 \\
\hline Jan V-30, $\mathrm{CCl}_{4}(<0.1$ vol \%) removed & 23 & 13 & 11 \\
\hline $\begin{array}{l}\text { Jan } \mathrm{V}-30, \mathrm{CCl}_{4} \\
\quad\left(<0.1 \text { vol \%) removed, } \mathrm{AO} \text { added }^{\mathrm{C}}\right.\end{array}$ & 23 & 15 & 8 \\
\hline $\begin{array}{l}\text { a. Milligrams per square decimeter pe } \\
\text { estimated accuracy of } \pm 15 \text { percent. } \\
\text { b. Oil stored over reagent for two wee } \\
\text { c. AO = antioxidant }(1000 \mathrm{mg} / \mathrm{l}) \text {. }\end{array}$ & ay. $A$ & lues he & \\
\hline
\end{tabular}

in the new oil. The main difference in the recovered oil shown in Table 6 versus Appendix 2 is that the former had been stored for over three months whereas the latter was less than one month old.

Using a simple laboratory-scale distillation technique, carbon tetrachloride was recovered from spent lathe-coolant mixtures to evaluate product purity. The oil mixtures were obtained directly from the machining areas since oil in Waste Tanks V-30 and V.-31 (see Table 3) contained other solvents. Characterization results of the reclaimed carbon tetrachloride are shown in Table 7.

No miscellaneous solvent contamination was detected by infrared spectroscopy techniques in
TABLE 7. Characterization Results of Reclaimed Carbon Tetrachloride

\begin{tabular}{|c|c|c|c|c|}
\hline Sample & $\begin{array}{c}\text { Oil } \\
\text { Content } \\
(g / 1)\end{array}$ & $\begin{array}{c}\text { Water } \\
\text { Content } \\
(\mu 1 / 1)\end{array}$ & $\begin{array}{l}\text { Plutonium } \\
\text { (mg/l) }\end{array}$ & $\begin{array}{l}\text { Plutonium } \\
\text { Corrosion Rate } \\
\left(\mathrm{mg} / \mathrm{dm}^{2} \cdot \mathrm{day}\right)^{\mathrm{b}}\end{array}$ \\
\hline 1 & 0.162 & 56 & $1.5 \times 10^{-6}$ & 77 \\
\hline 2 & - & 53 & $1.4 \times 10^{-6}$ & 74 \\
\hline 3 & 0.308 & 58 & $1.0 \times 10^{-6}$ & 75 \\
\hline 4 & 0.096 & 56 & $3.0 \times 10^{-6}$ & 64 \\
\hline 5 & 0.041 & 50 & $1.8 \times 10^{-6}$ & 78 \\
\hline 6 & - & 53 & $1.3 \times 10^{-6}$ & 70 \\
\hline new $\mathrm{CCl}_{4}$ & 0.004 & 59 & $1.2 \times 10^{-6}$ & 70 \\
\hline
\end{tabular}

a. Average of 7 and 14 day determinations; estimated accuracy $\pm 15 \%$. b. Milligrams per square decimeter per day.

the reclaimed carbon tetrachloride, but a small amount $(0.04$ to $0.30 \mathrm{~g} / 1)$ of oil was found. The oil contamination probably could be prevented by installing a trap between the distillation flask and the condenser.

Water concentrations in the reclaimed carbon tetrachloride were no greater than reagent-grade carbon tetrachloride $\left(59 \mu 1 / 1 \mathrm{H}_{2} \mathrm{O}\right)$ stored under the same conditions as the recovered carbon tetrachloride samples. Although the water concentration ( 0 to $150 \mathrm{ppm}$ ) was reported as varying linearly with relative humidity ( 0 to 100 percent $),{ }^{1}$ the water analyses obtained in this study were performed under low humidity conditions and the reagentgrade carbon tetrachloride was used as a control.

The samples of reclaimed carbon tetrachloride contained $<3 \times 10^{-6} \mathrm{mg} / \mathrm{l}$ plutonium (low enough to be recycled in plutonium handling areas) and were no more corrosive toward plutonium metal than new reagent-grade carbon tetrachloride. Increased levels of water in the carbon tetrachloride would increase plutonium corrosion; consequently, the relative humidity of air in contact with the carbon tetrachloride should be controlled. 


\section{CONCLUSIONS}

A research program was completed to determine the nature of plutonium in spent lathe-coolant oil and to develop methods for removing plutonium and for recycling the oil and carbon tetrachloride. The plutonium-contaminated lathe-coolant oil, with its carbon tetrachloride diluent, is generated in plutonium machining areas at Rocky Flats.

Studies showed that the mixtures of spent oil and carbon tetrachloride contained both particulate plutonium (identified as plutonium dioxide) and plutonium species that were soluble in water or in mixtures of oil and carbon tetrachloride (perhaps chloride and/or 2,6-Di-tert.-butyl-4-methylphenol soluble complexes). The particulate plutonium was removed by filtration; the soluble plutonium was removed by adsorption on various reagents. Charcoal appeared to be the most desirable adsorbent for removing soluble plutonium; however, additional studies are needed.
Laboratory-scale tests showed the lathe-coolant mixture could be separated by distillation of the carbon tetrachloride, provided the lathe coolant was free of other low-boiling solvents. The carbon tetrachloride and oil bottoms appeared acceptable for reuse. Recycling of the oil bottoms was dependent on the concentration of residual carbon tetrachloride in the oil and perhaps on deterioration of the oil with usage. Incineration of the oil bottoms should be evaluated as a step replacing the solidification-retrievable storage practice. The carbon tetrachloride recovery process will be evaluated on a large scale to further evaluate product acceptance and the economic feasibility of this process.

\section{REFERENCES}

1. J. L. Holst and D. K. Strangfeld. The Determination of Trace Residues on Metal Surfaces. RFP-419. The Dow Chemical Company, Rocky Flats Division, Golden, Colorado. November 16, 1964. 


\section{A P P E N D I X 1}

\section{Characterization of Lathe Coolant Oil}

\begin{tabular}{|c|c|c|c|c|c|}
\hline $\begin{array}{l}\text { Sample Date and } \\
\text { Tank Number }\end{array}$ & $\begin{array}{l}\mathrm{Pu} \times 10^{-5} \\
(\mathrm{~g} / \mathrm{l}) \\
\end{array}$ & $\begin{array}{c}\mathrm{Cl} \times 10^{-2} \\
(M) \\
\end{array}$ & $\mathrm{pH}$ & $\begin{array}{c}\text { Percent } \\
\mathrm{C}=\mathrm{O}^{\mathrm{a}}\end{array}$ & $\begin{array}{c}\text { Observed } \\
\text { Degradation } b\end{array}$ \\
\hline $\begin{array}{r}\text { Sept V-30 } \\
\text { (c) }\end{array}$ & $\begin{array}{l}886 \\
152\end{array}$ & $\begin{array}{l}0.8 \\
1.1\end{array}$ & $\begin{array}{l}2.6 \\
4.1\end{array}$ & $\begin{array}{l}0.09 \\
0.16\end{array}$ & $\begin{array}{l}\text { Major }(1,2,3) \\
\text { Minor }(1,2)\end{array}$ \\
\hline $\begin{array}{r}\text { Sept V-31 } \\
\text { (c) }\end{array}$ & $\begin{array}{r}116 \\
50\end{array}$ & $\begin{array}{l}0.2 \\
0.9\end{array}$ & $\begin{array}{l}3.0 \\
3.9\end{array}$ & $\begin{array}{l}0.08 \\
0.13\end{array}$ & $\begin{array}{l}\text { Major }(1,2,3) \\
\text { Minor }(1,2)\end{array}$ \\
\hline $\begin{array}{r}\text { Oct V-30 } \\
\text { (d) }\end{array}$ & $\begin{array}{r}157 \\
4\end{array}$ & $\begin{array}{l}0.3 \\
0.6\end{array}$ & $\begin{array}{l}2.9 \\
3.3\end{array}$ & $\begin{array}{l}0.04 \\
0.10\end{array}$ & $\begin{array}{l}\text { Major }(1,3) \\
\text { Minor }(1 ; 2)\end{array}$ \\
\hline $\begin{array}{r}\text { Oct V-31 } \\
\text { (d) }\end{array}$ & $\begin{array}{r}143 \\
35\end{array}$ & $\begin{array}{l}0.8 \\
0.3\end{array}$ & $\begin{array}{l}2.9 \\
4.2\end{array}$ & $\begin{array}{l}0.10 \\
0.17\end{array}$ & $\begin{array}{l}\text { Major }(1,2,3,4) \\
\text { Minor }(1,2)\end{array}$ \\
\hline $\begin{array}{r}\operatorname{Jan} V-30 \\
(\mathrm{e})\end{array}$ & $\begin{array}{r}57 \\
4\end{array}$ & $\begin{array}{l}0.2 \\
0.6\end{array}$ & $\begin{array}{l}3.0 \\
4.5\end{array}$ & $\begin{array}{l}0.04 \\
0.11\end{array}$ & $\begin{array}{l}\text { Minor }(1,3) \\
\text { Minor }(1,2)\end{array}$ \\
\hline $\begin{array}{r}\text { Jan V-31 } \\
\text { (e) }\end{array}$ & $\begin{array}{l}31 \\
22\end{array}$ & $\begin{array}{l}0.4 \\
3.4\end{array}$ & $\begin{array}{l}3.0 \\
5.6\end{array}$ & $\begin{array}{l}0.06 \\
0.12\end{array}$ & $\begin{array}{l}\text { Major }(1,3) \\
\text { Minor }(1,2)\end{array}$ \\
\hline $\begin{array}{r}\text { Apr V-30 } \\
\text { (f) }\end{array}$ & $\begin{array}{l}60 \\
16\end{array}$ & $\begin{array}{l}0.5 \\
0.8\end{array}$ & $\begin{array}{l}3.4 \\
4.9\end{array}$ & $\begin{array}{l}0.02 \\
0.09\end{array}$ & $\begin{array}{l}\text { Minor }(1,3) \\
\text { Minor }(1,2)\end{array}$ \\
\hline $\begin{array}{r}\text { Apr V-31 } \\
\text { (f) }\end{array}$ & $\begin{array}{l}46 \\
40\end{array}$ & $\begin{array}{l}0.6 \\
0.2\end{array}$ & $\begin{array}{l}2.7 \\
5.8\end{array}$ & $\begin{array}{l}0.04 \\
0.10\end{array}$ & $\begin{array}{l}\text { Major }(1,3) \\
\text { Minor }(1,2)\end{array}$ \\
\hline
\end{tabular}

a. Carbonyl stretching band. Relative oxidation measured as volume percent dibutyl sebacate in 643 oil. Unused 643 oils fresh from supplier's 55-gallon drums generally have oxidation levels in the $<0.010$ to 0.030 percent range. Measurements made on samples after removal of volatiles.

b. Observed degradation is determined by relative changes in the infrared spectra of $0.1-\mathrm{mm}$ films of the sample oils (after volatilization of halogenated hydrocarbons) over the 1250 - to $670-\mathrm{cm}^{-1}$ region against the spectrum of a fresh 643 oil. Observed changes in the spectrum include:

(1) Subtle changes in absorbance bands, and an increase in the overall absorbance from 1300 to $670 \mathrm{~cm}^{-1}$, because of normal degradation through use (e.g., chain cleavage, dehydrogenation, oxidation, nitration).

(2) Gross changes near $1700 \mathrm{~cm}^{-1}$ and 1100 to $900 \mathrm{~cm}^{-1}$ caused by radiolytic degradation, oxidation, and polymerization of the oil skeletal chain.

(3) Increase in the $1020 \mathrm{~cm}^{-1}$ absorbance resulting from the presence of siliceous matter (dissolved or suspended).

(4) Anomalous bands attributed to impurities such as silicone oils.

c. Stored oil and carbon tetrachloride in sealed polyethylene bottles for 10 months, then resampled.

d. Stored 9 months.

e. Stored 6 months.

f. Stored 3 months. 


\section{A P P E N D I X 2}

Characterization of Spent Lathe Coolant and Reclaimed Products

Carbon

Tetrachloride Oil Water Plutonium Chlorine Oxidation

\begin{abstract}
Descripiton
\end{abstract} (vol \%) $(\mathrm{g} / 1)$ (\%)
Plutonium

Corrosion $\left(\mathrm{mg} / \mathrm{dm}^{2} \cdot \mathrm{day}\right)^{*}$ After Degradation 1 Week 2 Weeks

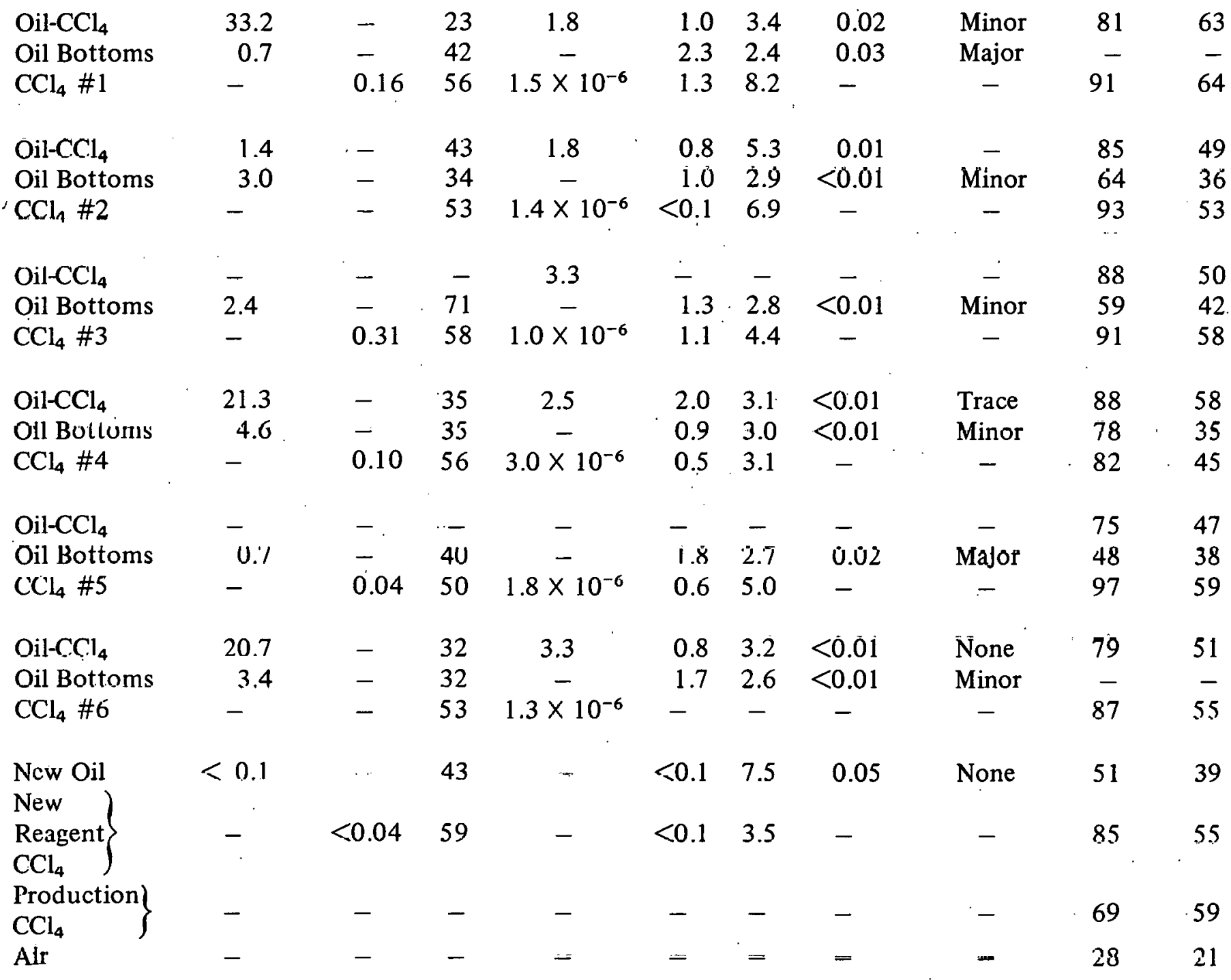

